\title{
JUDICIAL ETHICS SIMULATION BASED TRAINING
}

\author{
STEPHEN M. SimON AND MAURY S. LANDSMAN*
}

\section{INTRODUCTION}

The Judicial Ethics Education Project trains trial judges to be aware of ethical issues that arise in the trial process. The project employs case simulations that raise ethical and management issues requiring immediate attention during the course of a trial. The goal of the project is to provide sitting judges with a basis on which to make similar decisions during trials.

The project grew out of and is incorporated into the Minnesota Judicial Trial Skills Training Program ("MJTSTP") at the University of Minnesota, which was created in 1986 by Professor Steve Simon and Judge Bertrand Portisky and is mandatory for all newly appointed or elected Minnesota trial judges. ${ }^{1}$ It consists of a mock criminal trial scenario involving issues of scientific testing, control and management of firearms evidence, handling of exhibits, and use of documents. The volunteer attorneys are instructed to push the bounds of acceptable behavior and rules of evidence and decorum in the courtroom, giving the student judge an opportunity to exercise her administrative and adjudicative skills in a realistic setting. During the first eight years of its existence, the program did not focus on ethical issues. Issues of fundamental fairness and justice, however, were raised in the course of the trial. For example, one issue raised was when, if at all, a judge should intervene to "save" a criminal defendant from incompetent counsel. However, control issues and ethics issues are often intertwined, especially those concerning demeanor. ${ }^{2}$

Because the simulation deals with issues of judicial comportment, attorneyjudge relationships, and courtroom control, it does not depend upon any specific substantive area of law for its effectiveness and may be adapted to most areas of the law or for specialized courts. ${ }^{3}$ Similar simulations are already employed in legal education in other contexts, including law school clinics and classes ${ }^{4}$ and

Copyright $\odot 1996$ Law and Contemporary Problems

Clinical Professors of Law, University of Minnesota.

Riddhi Jani and Kristin Boetticher have given us valued assistance throughout this project. (1987).

1. See Stephen M. Simon \& Bertrand Poritsky, Judicial Trail Skills Training, 37 J. LEG. ED. 428

2. "Demeanor" in this context refers to judicial courtroom behavior in general and in specific behaviors that may be considered rude, indecorous, or biased.

3. The expansion of the program to include a broader and more specific ethics component was made possible by a grant from the W.M. Keck Foundation.

4. Paul Brest, A First-Year Course in the "Lawyering Process," 32 J. Legal EDUC. 344, 351 (1982)(first-year students at Stanford required to take a course taught in part through simulated clinical 
continuing legal education offerings. ${ }^{5}$ Computer-assisted legal education also includes some simulated activity. ${ }^{6}$ Literature and empirical data attest to the effectiveness of simulations. ${ }^{7}$ Some writers on professional education, such as Donald Schon, have set forth a theoretical basis that supports the use of simulations to train practitioners. ${ }^{8}$

Although a great deal has already been written on the substantive issues involved in judicial ethics-including texts that compile and analyze major judicial ethics problems, ${ }^{9}$ and materials that either discuss judicial ethics training or present actual curricula-our research reveals that there are no other simulations for judges that expressly raise issues of judicial ethics. ${ }^{10}$

Creating generally applicable simulations to train judges in judicial ethics is problematic. First, not all ethical issues judges face lend themselves easily to simulation training. For example, issues involving election campaigns are difficult to simulate. Scenarios involving investments or fundraising are also

exercises); Don J. DeBenedictis, Learning by Doing: The Clinical Skills Movement Comes of Age, 76Sep. A.B.A. J. 54, 57 (1990) (lawyering program required at New York University uses simulated interviewing, counseling, and advocacy); Nancy M. Mauerer \& Linda Fitts Mischler, Introduction To Lawyering: Teaching First Year Students To Think Like Professionals, 44 J. LeGAL EduC. 96 (1994)(extensive use of simulations in a non-traditional legal writing course at the Albany Law School, Union University); Unique Skills Program at William and Mary Uses Law Firm Model, 10 LAW HiRING \& TRAINING REP. 15 (1990)(students become associates in simulated law firms and handle a variety of cases over a two-year period).

5. Henry L. Hecht, Teaching the Teachers: How Simulation Workshops Benefit In-House Faculty, 12 LAW HIRING \& TRAINING REP. 4 (1992)(simulation workshops used in firms to teach associates lawyering skills provide "hands-on" training and the senior members of the firm, who act as faculty observers, become better supervisor); Richard D. Lee, The Organization and Role of In-House Training, ALI-ABA Course of STUDY, In-House Training: Maximizing Your LaWyers' Professional POTENTIAL 96 (1994)(many lawyering skills are best taught using simulations).

6. Margret M. Hazen \& Thomas Lee Hazen, Simulation of Legal Analysis and Instruction on the Computer, 59 IND. L.J. 195, 197 (1983).

7. According to James Moliterno, assistant professor and director of the legal skills program at William \& Mary, employers are praising his simulation-based program, and students are feeling more confident entering their summer clerkships. Unique Skills Program at William \& Mary, supra note 4, at 1; see also James E. Moliterno, Professional Preparedness: A Comparative Study of Law Graduates' Perceived Readiness for Professional Ethics Issues, 58 LAW \& CONTEMP. PROBS. 259 (Summer/Autumn 1995). The same program received first prize in the $1991 \mathrm{E}$. Smythe Gambrell Professionalism Award competition from the American Bar Association's Special Coordinating Committee on Professionalism. Anne Melissa Rossheim, William \& Mary's Legal Program Wins ABA Award, 11 LAW HIRING \& TRAINING REP. 15 (1991).

At the University of Minnesota School of Dentistry, Dr. Muriel Bebeau and others have been using simulation programs to teach ethics in dentistry. Their ongoing studies have dispelled the belief that ethics cannot be taught, and they have found that their curriculum, with extensive use of simulations, can measurably influence ethical development. Muriel J. Bebeau, Influencing the Moral Dimensions of Dental Practice, in Moral Development in THE PROFEssions: Psychology AND APPLied ETHICS (James R. Rest \& Darcia F. Narvaez eds., 1994).

8. See generally Donald SChOn, EduCATING THE Reflective PRACTITIONER (1986); Donald SCHON, THE Reflective PRACTITIONER: HOW PROFESSIONALS THINK IN ACTION (1983).

9. See, e.g., JefrRey M. Shaman et Al., Judicial Conduct and ETHICS (2d Ed. 1995); MINNESOTA SUPREME COURT, TASK FORCE ON GENDER FAIRNESS IN THE COURT, 1989 FinAL REPORT (1989); Symposium: Improving Communications in the Courtroom, 68 IND. L. J. 1061 (1993).

10. There are few casebooks or treatises used in law school instruction that educate students about the doctrine or skill of judging. We have found only one. See Robert E. KEETON, Judging (1990). Likewise, until recently there were no formalized programs to provide training and education for judges. 
difficult to create in the trial context. Although it may be possible to create seperate role-plays raising these issues, the issues have been successfully incorporated in the MJTSTP as a potential conflict of interest when a lawyer appears before a judge to whom he made campaign contributions.

A second problem in creating judicial ethics simulations is that the sources of the ethical principles governing judges vary from jurisdiction to jurisdiction. The American Bar Association ("ABA") promulgated a Model Code of Judicial Conduct in 1972, amending it 1982, 1984, and 1990. The Code consists of norms and standards designed to regulate judicial behavior on and off the bench. ${ }^{11}$ State courts and commissions publish opinions and decisions in cases of judicial misconduct, ${ }^{12}$ which inevitably illustrate differing interpretations of either the ABA's code or the state code of judicial conduct. However, even if the solutions differ from jurisdiction to jurisdiction, the underlying problems remain the same. Because our program is aimed at raising issues rather than determining the correct answers, it can be adapted to different jurisdictions.

The third problem in creating judicial ethics simulations is that some of the ethical prescriptions for judges are general, vague, and give little guidance about the appropriate conduct in many situations. ${ }^{13}$ As a result, it is often difficult to resolve a demanding ethical dilemma without reflection and without a solid foundation of judicial experience. Even where there are discernible answers, it is difficult to come up with solutions to complex or new issues "on the fly" in the midst of a hearing.

The fourth problem is that different courts have different functions. General civil courts may be primarily concerned with the resolution of disputes in commercial, tort, and other cases. Specialized courts, however, may have other functions that affect the way in which ethical issues should be resolved. For example, criminal courts have a special duty to ensure that the rights of defendants are protected; likewise, family, probate, and juvenile courts have a mission to protect vulnerable members of society.

Finally, there is disagreement among persons of good faith and intelligence as to the proper course of action to take in many circumstances. Moral disagreement, especially on fundamental issues, is a fact of life, and we should not be surprised that judicial ethics gives rise to such disputes. While we may agree that fairness and justice should be among the primary guiding missions of

11. See generally Lisa L. Milord, The Development of the ABA Judicial Code (1992). Forty-seven states have judicial codes based on the 1972 ABA Model Code of Judicial Conduct. Nine states have adopted the 1990 Revised Code. In many state jurisdictions, case law and advisory opinions modify and explain the broad meaning of the canons in different ways, so it is always important to know to what extent the code in one's jurisdiction deviates from the Model Code. JEFFREY M. Shaman \& CYNTHia GRAY, Judicial ConduCT AND ETHICS CuRRICUlum 3 (1993).

12. For the breadth of reports and cases, see generally JUDICIAL DISCIPLINE AND DISABILITY DIGEST (Judith Rosenbaum ed., 1981 \& Supp; Sara Mathias ed., 1991).

13. Peter W. Morgan, The Appearance of Propriety: Ethics Reform and the Blifil Paradoxes, 44 STAN. L. REV. 593, 607-610 (1992)(the ethical guidelines applied to so many professionals including government officials, lawyers, and judges are much too vague to be illuminating and are subject to manipulation by unscrupulous individuals wanting to attack relatively innocent individuals). 
the court, we may disagree on what constitutes justice or fairness in general or in any particular case. Moreover, despite our commitment to fairness and justice, we unfortunately often have to balance these goals against interests of efficiency and economic constraints. Because the way in which the balance is maintained is a matter of judgment, simulations cannot lead judges to any "right" answer. All simulations can do is give judges an opportunity to exercise judgment.

The simulation currently used in MJTSTP is a criminal case involving weapons possession and driving under the influence of intoxicating beverages. The simulation begins with the prosecution questioning its witness, a police officer who arrested the defendant the night he was allegedly driving drunk and in possession of a firearm. The attorneys are asked before the simulation to initiate ex parte communication, raise control issues, use biased language, request the judge to recuse herself, and to raise these issues faster than the student judge can deal with them. ${ }^{14}$

In selecting experienced judges to critique the student judges, we try to select judges who have participated in the simulation previously and who appear to have good evaluation skills. Since we believe that gender and race may bring unique problems in some areas for judges, we have also tried to find senior women judges to critique new women judges. We have been less successful in matching experienced judges of color to new judges. Recently, we have engaged Professor Mary Jane Madden, a communications specialist in the School of Public Health, Division of Health Management and Policy, to assist us in our critiques.

Students usually play the role of witnesses, and Professor Simon or Landsman acts as bailiff, clerk, or court reporter. The simulated trial lasts for about one hour and is videotaped. The senior judge observes the trial and makes notes on the student judge's performance. The attorneys give brief feedback to the student judge, and the senior judge then reviews the videotape of the session privately with the student judge. Although few senior judges have availed themselves of the opportunity to participate in the simulations as student judges, the program would be of greater benefit if it were repeated sometime during the first year of judging and then, as a refresher, occasionally thereafter.

The following discussion identifies some of the ethical issues that judges frequently encounter and describes how the issues have been dealt with in the case law and how they are raised to the new judge in simulations.

14. The attorneys participate voluntarily and consider it an honor to be invited to do so. The senior judges who act as evaluators are given release time from their bench duties to participate in the program. None of the participants is compensated for her or his time other than continuing legal education credits for the attorneys. 
II

\section{ETHICAL IsSUES FReQUENTLY FACED By JUDGES}

We surveyed judicial educators throughout the United States and discovered that the issues most frequently giving rise to complaints against judges include ex parte communication, bias, political activity, and demeanor. ${ }^{15}$ The goal of our program is to train judges to recognize the difficult problems that arise and to equip the judges with the conceptual tools to resolve the problems and make informed judgments where there are no clear answers.

\section{A. Ex Parte Communications}

Ex parte communication is one of the most common areas of judicial misconduct complained about by the public. Ex parte communication is any kind of undisclosed conversation, discussion, or statement, either verbal or written, made by the judge about the case either to a party or a non-party to the proceedings outside the presence of one of the parties and which could affect the rights of the parties. The Code of Judicial Conduct provides guidelines and procedures for accomplishing necessary ex parte communication. ${ }^{16}$

Issues of ex parte communication may generally be divided into three categories. First, there are ex parte communications made between the judge and a party to the litigation, a lawyer from either side, or a litigant. Second, there are ex parte contacts between the judge and a non-party to the litigation (such as law professors, or rehabilitation and other criminal justice professionals), where the judge's purpose in contacting the non-party is to ask for advice, elucidation, or clarification of a legal matter. Third, there are ex parte communications where the judge's purpose is not to gain useful information from the person with whom she or he communicated, but rather to use her or his judicial office to seek favor in a case in which the judge has some kind of personal interest.

Ultimately, the key criterion for determining whether an ex parte communication is approved judicial conduct is to ascertain whether the communication is likely to compromise the judge's appearance of impartiality. This is the ultimate test adopted by the majority of the reviewing courts, and it is a most useful guide for all uncertain judges.

In our simulated criminal trial, we raise the issue of ex parte communication by having the defense attorney's beeper go off in the middle of the trial. The attorney then explains to the judge that someone in his family is having surgery and that he was to be paged when the surgery was complete. The attorney then asks permission to return the phone call to make sure that everything is okay.

15. Professor Landsman has the survey results on file at the University of Minnesota Law School.

16. MODEL CODE OF JUDICIAL CONDUCT Canons 2B, 3B(7) (1990)(extra-judicial consideration; ex parte communications); see generally JEFFREY M. SHAMAN ET AL., JUDICIAL CONDUCT AND ETHICS (2d ed. 1995). 
The judge usually grants the request. While the defense attorney is out of the room, the prosecutor attempts to make conversation with the judge about the seriousness of gun and alcohol cases. The judge must quickly make it clear to the prosecutor that her attempts to influence the court will not be tolerated, and the judge must decide whether to inform the defense attorney of what was said while he was gone. Further, if it is a jury trial and the jury is present, the judge must also decide whether the prosecutor's comments warrant specifically directing the jury to disregard them.

Some additional examples of ex parte communication that raise ethical questions and that may be effectively included in simulation exercises are the following: one lawyer leaves the courtroom and the remaining lawyer makes conversation to the judge privately about something embarrassing to the witness $;{ }^{17}$ the judge asks one of the lawyers to draft an order without announcing the decision beforehand (prohibited) or after announcing the decision (permitted) $;{ }^{18}$ and a guardian ad litem for children in a divorce contacts the judge ex parte. ${ }^{19}$

\section{B. Impartiality, Conflicts, and Disqualification}

The appearance of impartiality is a key precept of the Model Code of Judicial Conduct. ${ }^{20}$ Many of the canons spring from the requirement of impartiality. ${ }^{21}$ One study considered the way judges' actions and behaviors on the bench affect jury verdicts. ${ }^{22}$ The study divided judges' behavior into two categories: global behavior, which reflects judges' communicative styles and helps predict trial outcomes, and micro behavior, which is other nonverbal behavior, such as eye contact, smiles, and hand or head movements. ${ }^{23}$ The study found that a judge may send two very different messages through these separate modes of communication. For example, in a case where the judge believes that past criminal history leads to an inference of guilt, the judge's

17. The 1991 California Commission on Judicial Conduct Annual Report States that it is misconduct for a judge to meet with a reluctant or nervous witness ex parte to encourage her or him to testify. SHAMAN \& GRAY, supra note 11 , at 13 (1993).

18. See In re McCormick, No. 85-7-372-10 (Unreported Determination Chief Judge of the 7th Cir. May 7, 1985)(ruling that judge's ex parte communication with counsel for the debtor in a bankruptcy case, telling him to propose orders and then presenting orders as judge's own, violated Canon 3B(7)(former Canon 3A (4)). Cf. In re X-Cel, Inc., 61 B.R. 691, 695 (Bankr. N.D. Ill. 1986) (ruling that creditor's counsel's ex parte communication with judge not sufficient for disqualification).

19. The prohibitions against ex parte communications were violated where a judge privately met with a ward, hired a law professor to review an estate plan drafted by the ward's conservator, and excluded a co-conservator from conversations. In re Kinsella, 476 A.2d 1041, 1046-47 (Conn. 1984).

20. MODEL CODE OF JUDICIAL CONDUCT Canon 2(A)(1990)(appearance of impropriety); see SHAMAN ET AL., supra note 16.

21. Model Code of Judicial Conduct Canons $1,3(\mathrm{~B})(5), 3(\mathrm{~B})(10), 3(\mathrm{C})(1), 3(\mathrm{E})(1)(\mathrm{a})(1990)$ (integrity and independence of the judiciary; performance of judicial duties without prejudice; treatment/jurors; administrative responsibilities; disqualification for personal ties); see SHAMAN ET AL., supra note $16, \mathrm{ch} .3$ and cases cited therein.

22. Peter David Blanck, Calibrating the Scales of Justice: Studying Judge's Behavior in Bench Trials, 68 INDIANA L.J. 1119, 1126 (1993).

23. Id. 
overt, verbal behavior on instructions may be perceived as judicial, directive, and warm, while the judge's nonverbal behavior reveals her or his true feelings.

The cases illustrate the high value that judicial standards boards and commissions place on the requirement of impartiality. ${ }^{24}$ Even in cases where a judge defends a slur or justifies a particular act as being in the interest of judicial efficiency, ${ }^{25}$ the misbehavior is, in almost all cases, deemed inappropriate. Even if the judge's actions were in good faith, the courts conclude that the appearance of impropriety resulted in a diminution of public confidence in the judiciary.

Today, new judges may be in greater need of training on these ethical issues than ever before. Given increasing specialization, more and more judges come to the bench from a practice limited to one or two areas of the law. Differing perceptions of appropriate behavior may come from experiences in varied legal backgrounds. Additionally, each individual brings her own set of biases to the bench from her own life experiences. In MJTSTP, we try to get the judge to recognize the limits of her practice and recognize biases, set them aside, and maintain both the appearance and reality of impartiality.

The Code of Judicial Conduct ${ }^{26}$ and the case law identify at least five discernible grounds for disqualification and recusal on the basis of potential conflict of interest: (1) relationship to a party; (2) relationship with an attorney; (3) former counsel to a party; (4) interest in the case; and (5) bias and prejudice. Simulations may also present conflicts of interest ${ }^{27}$ and possible grounds for disqualifications in the following areas: the difference between a campaign contributor and member of the campaign committee appearing before the judge ${ }^{28}$ a non-waivable conflict for personal bias; and peculiar problems in rural jurisdictions. ${ }^{29}$

24. See In re Rasmussen, 734 P.2d 988, 989 (Cal. 1987)(judge displayed a lack of impartiality to and harassment of the attorneys who filed affidavits of prejudice against him, violating Canons 2 and 3 (c)(1) of the Code); see also Matthews v. State, 854 S.W.2d 339, 341 (Ark. 1993) (judges must refrain from presiding over cases in which they might be interested and avoid all appearance of bias); Forsmark v. State, 349 N.W.2d 763, 767 (Iowa 1984) (Code of Judicial Conduct is a "guiding precept upon which every judge, by an objective in-depth search of his or her own conscience, must decide whether a fair trial dictates, that he or she should make way for another judge to preside.").

25. See In re Paulsy, 318 S.E.2d 418, 422 (W. Va. 1984) (magistrate suspended after failing to follow basic criminal procedure); see also In re Clavin (NY Comm'n on Jud. Conduct, Dec. 28, 1981) (ruling that "the deficiencies of the physical plant, the crowded court calendar, and the general atmosphere of tension in the small claims court" did not excuse judge who was impatient and discourteous, intimidated defendant, and projected himself into the trial in a prosecutorial manner).

26. SHAMAN ET AL., supra note 16, at 95.

27. In Canon $3(\mathrm{C})$, the Code identifies three areas that give rise to conflicts of interest: the judge's (1) personal bias or prejudice, (2) professional and personal relationships, and (3) economic interest in the litigation. Disqualification is necessary when these situations might reasonably throw the judge's impartiality into question. MODEL CODE of JUdiclal CoNDUCT Canon 3(C)(1990).

28. See discussion in SHAMAN ET AL., supra note 16, at 394-98.

29. The network of a judge's acquaintances that develops in a small community can present unique ethical dilemmas. With regard to the duty to sit, a West Virginia judge said that too many voluntary disqualifications arose in rural jurisdictions because of the greater frequency of relationships between judges and parties, lawyers, and others involved in cases. Membership in discriminatory organizations may also cause more problems for rural judges. Some participants at the conference felt that not 
The fact pattern used in the MJTSTP raises issues of impartiality and economic conflict by informing the student judge that she and the prosecutor jointly own a boat and that the defense attorney has made a campaign contribution to the judge. The student judge and both of the attorneys are made aware of these facts prior to the exercise; the judge must decide how to deal with the information. If the judge does not disclose the information at the beginning of the trial, one of the attorneys is instructed to stand up during the trial and state that she has been made aware of the economic interest that the judge shares with opposing counsel and make a request for recusal. ${ }^{30}$ Even if the judge discloses the information and both counsel state on the record that they have no problem with the relationship, later in the trial, after numerous objections are sustained or overruled, the objecting attorney may still ask for disqualification on the grounds of the joint interest because it is apparent by the way the judge is conducting the proceedings that she or he is influenced in favor of the other attorney.

\section{Political Campaigning}

The Code of Judicial Conduct limits judges' writing and speaking about the law and the administration of justice so that such activities do not interfere with the judge's ability to act as an impartial arbiter in any case that may come before the bench. ${ }^{31}$ Naturally, there is a significant overlap between judges engaging in avocational activities that contribute to the improvement of the law and the legal system, and a judge speaking out as part of a political campaign. The former is generally permitted. The latter is permitted for limited political purposes. The misconduct cases $^{32}$ and articles concerning political activity emphasize the idea that judges should maintain the dignity appropriate to judicial office. This means that even when engaging in political campaigning, judges should not make pledges or promises of conduct in office other than the promise to faithfully and impartially perform their duties. Nor should they announce their views on disputed legal or political issues, or misrepresent their identity, qualifications, or present position. As noted, we have considered, but not implemented, the case of a judge being a prominent member of an advocacy organization such as Mothers Against Drunk Driving before her service on the bench.

The Code of Judicial Conduct recognizes that judges "must respect and honor the judicial office as a public trust and strive to enhance and maintain

\footnotetext{
belonging to certain clubs with discriminatory membership would be political suicide. Lisa L. Milard, 13th National College on Judicial Conduct and Ethics Encourage Debate, 76 JUDICATURE 201 (1993).

30. In presenting this issue before the National Council of Family and Juvenile Court Judges in July 1995 , one of the authors found almost unanimous support for disqualification of the judge in one of our simulations despite hardship to the parties.

31. MODEL CODE OF Judicial CONDuCt Canons 3(A), 4(A), 4(B), 5(A)(3)(d) (1990)(judicial duties in general; judges conducting extra-judicial activities to minimize conflicts; judges refraining from inappropriate political activity); see SHAMAN ET AL., supra note 16.

32. See cases collected in SHAMAN ET AL., supra note 16, ch. 3.
} 
confidence in our legal system.." ${ }^{33} \mathrm{~A}$ judge, therefore, should conduct his or her extra-judicial activities in a responsible manner and minimize the risk of conflict with judicial obligations. Although the scope of activities and speech that a judge may engage in as part of a political campaign is not clearly defined, the commentary to the Code provides useful guidance $;^{34}$ a candidate for judicial office shall maintain the dignity appropriate to judicial office and act in a manner consistent with the integrity and independence of the judiciary. The cases recognize that political campaigning is a necessary and inevitable part of the election process, and, therefore, reviewing committees have usually allowed most kinds of political speech, provided it is not overly compromising and does not reflect poorly on the judiciary as a whole.

As discussed above, it is difficult to integrate political campaign issues into the trial simulation. We have raised the issues by informing the student judge that the defense attorney has made a $\$ 500$ contribution to the judge's campaign. Both of the attorneys and the judge are made aware of this fact prior to the trial. The judge must independently decide whether to disclose the information. If the judge does not disclose the information at the beginning of the trial, the prosecutor informs the judge during the trial that he is aware of the interest and asks the judge to disqualify herself.

\section{Race, Gender Bias, and the Judge's Demeanor}

In an increasingly diversified society, dealing with the reality of race and gender bias in the courtroom is gaining greater importance for judges. The Code of Judicial Conduct ${ }^{35}$ as well as the $\mathrm{ABA}^{36}$ have policies against race and gender discrimination, but it is a much more difficult step to identify, prove, and remedy the existence of gender and racial bias in legal proceedings.

As reported in several state task force reports, law review surveys, ${ }^{37}$ and newspaper reports, sexual harassment by judges is a widespread problem. ${ }^{38}$

33. Model Code of Judicial Conduct preamble (1990).

34. Id. Canons 4 and 5 .

35. Id. Canon 3(B)(6) ("A judge shall require lawyers in proceedings before the judge to refrain from manifesting, by words or conduct, bias or prejudice based upon race, sex, religion, national origin, disability, age, sexual orientation or socioeconomic status against parties, witnesses, counsel, or others ...."); see SHAMAN ET AL., supra note 16, at 74-90.

36. The ABA's proposed solution is the Model Code of Judicial Conduct. The new Model Code now explicitly prohibits sexual harassment: "A judge must refrain from speech, gestures or other conduct that could reasonably be perceived as sexual harassment." MODEL CODE OF JUDICIAL CoNDUCT Canon 3(B)(5) (1990). The ABA's comments and the Supreme Court statement that "the mere existence of a grievance procedure and a policy against discrimination ... [cannot] insulate [the employer] from liability," Meritor Savings Bank FSB v. Vinson, 477 U.S. 57, 72 (1986), are positive steps toward eliminating gender bias generally.

37. In Minnesota, $15 \%$ of women lawyers reported that women litigants or witnesses receive verbal sexual harassment sometimes or often; $47 \%$ reported demeaning jokes in chambers. Marina Angel, Sexual Harassment by Judges, 45 U. MIAMI L. REV. 817, 820 (1991).

38. California's Judicial Performance Commission asked the California Supreme Court to remove a judge from the bench for, inter alia, jailing a defendant because he refused to plead guilty, dismissing drug charges against a female defendant because she "had shown the judge her breasts," improperly urging a prosecutor to bring felony charges against a defendant whose case the judge was hearing, and 
One common harassment situation occurs when the judge consciously makes remarks, advances, or gestures to female participants in the courtroom or in chambers. $^{39}$ A more common form of harassment occurs when a judge knowingly or unwittingly uses terms of endearment toward female lawyers, litigants, or personnel. The Missouri Task Force revealed that judges are frequently oblivious to the fact that they have made a demeaning comment. ${ }^{40}$ Further, women on the receiving end of this treatment are often reluctant to complain about the judges' misbehavior because they fear jeopardizing their positions in court.

Recommendations to combat sexual harassment by judges focus on the power structure of the courtroom. The barrier of the judge's perceived power needs to be dismantled in order to confront these cases. In situations where the judge is not engaging in the sexual harassment, but presides over a courtroom where there is sexual harassment, both the Minnesota Court and the Ninth Circuit task force urged a much more active role for the judge in eliminating gender bias. ${ }^{41}$ Before the judge can reach a point at which she or he can successfully eliminate gender bias in the courtroom, the judge needs to be aware that it is occurring. This can be achieved through gender-sensitivity training and through codification and guidelines for gender-neutral behavior. Once there is heightened awareness of gender issues within the judiciary, the judge's role as the setter of norms becomes even more crucial in ensuring gender fairness.

Judges acknowledge racial bias in court far more than gender bias. Racial bias may be intentional, such as slurs, or just inadvertent insensitivity driven by ignorance. $^{42}$ For the first type of racial bias, numerous task forces and the popular press have stressed the need for formal grievance procedures. For the latter problem, judicial training in this area needs to develop cultural sensitivity, rather than simply instructing judges as to what not to do or say.

One further important aspect to both race and gender bias in the courtroom concerns the communication between the judge and jury. ${ }^{43}$ One study has found that non-verbal judge and jury communication was one of the most crucial elements precipitating bias in the courtroom. The judges' silent gestures were quickly perceived by the jury and frequently determined the outcome of

telling obscene jokes in chambers. Judge Faces Ouster on Charges of Misconduct, L.A. TIMES, Nov. 8, 1986, Metro 2.

39. Sixty percent of the Ninth Circuit's female lawyers claim to have been the target of unwanted sexual advances from judges, lawyers, or court personnel. Symposium: Special Section Report of the Ninth Circuit Gender Bias Task Force, 45 STAN. L. REV. 2153, 2163 (1993).

40. REPORT OF THE MISSOURI TASK FORCE ON GENDER AND JUSTICE 220 (Mar. 1993).

41. See The Effects of Gender Bias in the Federal Courts: The Final Report of the Ninth Circuit Gender Bias Task Force, 67 S. CAL. L. Rev. 745, 959-60 (1993); Minnesota Supreme Court Task Force for Gender Fairness in the Courts: Final Report, 15 WM. MITCHELL L. REV. 825, 931-34 (1989).

42. In one survey, $41 \%$ of metropolitan judges under 50 -years-old responded that judges sometimes display culturally insensitive behavior, and $21 \%$ of the group noted that judges sometimes make demeaning remarks or jokes about people of color in court or chambers. Symposium: Racial Bias in the Judicial System, 16 HAMLINE L. REV. 477, 505 (1993).

43. Peter Blank, Symposium: Improving Communication in the Courtroom, Calibrating the Scales of Justice: Studying Judge's Behavior in Bench Trials, 68 IND. L.J. 1119 (1993). 
the case. Recommendations to improve communications include more frequent interaction between the judge and jury to ensure that the jury does not impart undue significance to every expression the judge makes.

The judges' demeanor in the courtroom-regardless of his or her actual bias-can be equally harmful to the administration of justice. However, critiquing the appropriateness of the judges' demeanor can be quite difficult, because it encompasses a host of verbal and nonverbal cues that can affect the fairness of the trial. The following are types of behavior that have provoked inappropriate reactions from judges and have resulted in discipline that may be simulated effectively: a party violates rules of evidence, procedure, decorum; a witness speaks to her attorney after the judge asks a question; ${ }^{44}$ a spectator is disruptive; ${ }^{45}$ existence of non-verbal communications including facial expressions, body language, and positioning; a witness who is disruptive, confused, or otherwise difficult argues with counsel or asks the judge questions; lawyers use demeaning language toward witnesses and each other.

Although the different approaches in each jurisdiction make it difficult to draw from the case law any specific conclusions about the treatment of bias and demeanor issues in judicial behavior, several general findings can be made. First, the state commissions and the courts consistently emphasize that race, gender, and ethnic bias have no place in the justice system. ${ }^{46}$ Second, in cases where the judge defends a slur or justifies a particular decision as being in the interests of judicial efficiency, the misbehavior is in most cases deemed inappropriate. Finally, in cases where the judicial conduct is questionable but not patently offensive, such as risqué humor, the courts or commissions will examine the entire record of the judge rather that making a judgment from a single incident. The factors usually weighed are public confidence in the judiciary and the fair exercise of judicial authority.

Prior to the MJTSTP training exercise, we ask the attorneys to push the boundaries of decorum in a number of ways, including making sexist or racist comments. For example, in one session, the male defense attorney refers to the female prosecutor as "honey." He goes on to call her "baby" and to insinuate a sexual relationship between her and the witness. The critiquing judge did not think that the student judge sufficiently admonished the attorney for these remarks and noticed that the female attorney had to bring the remark to the judge's attention. The male attorney only apologized to the court and not to opposing counsel. In another session, members of the audience, all judicial educators, perceived the student judge as giving deferential treatment to the male prosecutor over the female defense counsel. On this occasion, neither the

44. Kloepfer v. Commission on Jud. Perf., 782 P.2d 239, 251-52 (Cal. 1989) (removing a judge for lack of judicial temperament and citing as evidence the judge's extreme reaction to defendant's whispering to defense counsel that he did not understand the judge).

45. Id. at 254-55 (citing as evidence of lack judicial temperament judge finding spectator in contempt without explanation when spectator swore after tripping over son's feet).

46. SHAMAN ET AL., supra note 16, at 74-85. 
critiquing judge nor the attorneys mentioned any appearance of gender bias in the student judge's performance. This demonstrates the varying degrees to which people are sensitized to and aware of gender and racial bias issues. ${ }^{47}$

The simulations also illustrate different trial and courtroom dynamics by way of the composition of the players in the courtroom. For instance, in one simulation, everyone in the courtroom happened to be white except the defense counsel, the defendant, and the defendant's family, who were African-American. The defense counsel asked the judge to recuse himself on rather vague grounds, leaving open the question of whether he thought the judge was biased because he owned a boat with the prosecutor or because of race. In many jurisdictions, African-American judges and attorneys are few and far between. Often, the only African-American in the courtroom will be the defendant and the defendant's family. ${ }^{48}$ Judges need to be aware of how such a power differential can affect justice and fairness in the court room. However, this kind of dynamic is often difficult to create for many reasons, not the least of which is the under-representation of people of color in the legal profession.

\section{E. Justice Issues: The Duty to Intervene}

Our research indicates that the judge has an affirmative duty to intervene in questioning witnesses or litigants in two basic situations. First, where there is some patently obvious evidence or information that the lawyer for either side has neglected to raise. The case law suggests that intervention in these circumstances, to ensure that vital pieces of information are not omitted, is exactly the type of situation warranting an affirmative duty to intervene. The imposition of this duty is generally justified as being a function of the judge's job to further the aims of justice and to ensure that the defendant is not denied the effective assistance of counsel in particular. The second, related situation in which judges are required to intervene is when it is necessary to ensure that the case is presented fairly in the eyes of a jury. If there is a severe mismatch between the attorney's skills resulting in a "farcical" trial, the judge must act to ensure that the trial is fair.

The reviewing courts have focused on the importance of presenting evidence to the jury in a neutral, digestible manner, rather than from a one-sided, slanted angle that could result from mismatched attorney skills. Thus, the judge's duty of intervention is still focused upon "justice issues," but the parameters of this

47. Fifty-one percent of male attorneys said that judges often or always correct gender-biased behavior in the courtroom, while only $13 \%$ of the female attorneys said that judges always or often intervene. Minnesota Supreme Court Task Force for Gender Fairness in the Courts, Courtroom Environment, 14 WM. MITCHELL L. REV. 923, 932 (1989).

48. Five percent of the judges and $3 \%$ of the attorneys in the state as a whole are people of color. The 1992 survey of this Task Force suggests that there needs to be more cultural sensitivity training in the predominantly white justice system. Symposium: Racial Bias in the Judicial System, supra note 42, at 490 . 
duty are blurred due to the extent the judge needs to intervene to ensure fairness and the difficulty of discerning the jury's perception.

A related problem is caused by excessive judicial intervention. Attorneys may not feel comfortable or confident in approaching the judge when the attorney feels the judge has been questioning too vigorously or participating too much. Judges must be aware of the tension and conflicts created by their acts. This is especially true in cases where the judge intervenes on behalf of the criminal defendant causing the prosecution to feel "victimized" by the court because of the shortcomings of defense counsel. To ensure that the judge's intervention does not isolate the opposing attorney, the judge should provide opportunities to respond to the judge's questioning, not single out either side for special treatment, ${ }^{49}$ and ultimately limit questioning when it borders on the egregious. ${ }^{50}$

The cases that have held against judicial intervention involve over-extensive questioning of parties, dispelling the impartiality of the judge, and creating a prima facie case of prejudice by the judge. Too much intervention on the part of the judge usually involves badgering the witnesses and hammering a point beyond the requirements necessary to achieve "justice." 11

Overall, however, the judge can maintain the appearance of impartiality by ensuring her intervention is fairly equal for both sides by making it clear when necessary that questions are asked for clarification, and by couching questions in value-neutral terms. A judge who makes timely, infrequent interventions when it is apparent that the criminal defendant is being denied a fair trial acts well within ethical bounds.

In the MJTSTP fact pattern, the prosecutor asks a police officer witness to give the results of the defendant's breath alcohol test without first laying a sufficient and proper foundation. Prior to the simulation, we ask the defense attorney to appear momentarily distracted and to fail to object to this question. We also ask the witness to pause before answering in order to give the student judge an opportunity to intervene on behalf of the defendant. If the judge does not intervene, the defense attorney eventually objects. What should the judge do? While not normally considered an issue of ethics, we believe this part of the simulation raises fundamental issues concerning the ability of the legal system to deliver substantive as well as procedural fairness, especially in criminal cases. The fairness and justice of the legal system depends on the clash of two relatively equally prepared and competent attorneys. The reality is that some

49. Note that the Sixth Amendment right to counsel may produce differences between the judge's duty to intervene on behalf of the prosecution and the defense.

50. United States v. Green, 429 F.2d 754, 760-61 (4th Cir. 1970); United States v. Stirrone, 311 F.2d 277, 279-90 (3d Cir. 1962).

51. In receiving a commission's determination of judicial misconduct, an appellate court rejected a judge's explanation that he was legitimately concerned for a minor's welfare and firmly convinced that certain witnesses were credible. The court stated, "A trial judge may not . . . in the course of examining witnesses, become an advocate for either party or cast aspersions or ridicule upon a witness." Roberts v. Commission on Jud. Perf., 661 P.2d 1064, 1069 (Cal. 1983). 
attorneys are smarter, harder working, better prepared, or more competent than others. What is the judge's role if, for example, a defense attorney is asleep at the wheel and about to let the inadmissible smoking gun be introduced without objection? What if it is the prosecutor? Is there a difference between civil and criminal proceedings? Jury and non-jury trails? What about the unique issues raised in juvenile court? ${ }^{52}$ Our simulation attempts to raise some of these issues.

\section{III}

\section{CONCLUSION}

Although we have not conducted any significant follow-up with the approximately twenty-five new judges who have gone through the MJTSTP, we have recieved many positive anecdotal responses. However, it is difficult to tell whether a single simulation in fact makes new judges sensitive to the ethical issues that arise during trial. Groups of juvenile, family, and military judges have also gone through MJTSTP. The most noticeable result has been the increased, consistent refusal of judges to engage in ex-parte communications and the great diversity of responses to the conflict of interest issues. Our experience has shown that the ex-parte issues are easier to resolve than the more nuanced conflict issues, and that gender bias issues are raised more easily in this program than are issues of race bias.

The program would be more effective if it could be given once at the beginning of the judge's career, again one year later, and then occasionally throughout her career. The program's effectiveness would also be enhanced if it were given over a longer period with more time for reflection and reading in preparation for repeating the exercise. Nonetheless, even without these modifications, the program has sensitized the participating judges to some of the ethical issues that will arise in the course of trials. It can also be easily tailored to fit the needs of other jurisdictions and specialized courts.

52. Judicial intervention in juvenile cases is not based so much on formal decisional rules as on the court's factual determinations about the child's life, character, environment, and social circumstances. Juvenile court judges have a broad mandate to determine the best interests of the child, which exacerbates the potential effects of intervention in witness examination. When the judge intervenes, it is difficult to evaluate objectively whether the intervention meets the same standards of impartiality and fairness required in adult criminal cases. Barry Feld, The Juvenile Court Meets the Principle of the Offense: Legislative Changes in Juvenile Waiver Statutes, 78 J. CRIM. L. \& CRIMINOLOGY 471 (1987). 